\title{
Opportunities and challenges associated with fecal progesterone metabolite analysis
}

\author{
Innocent Damudu Peter ${ }^{1,2}$, Abd Wahid Haron ${ }^{1}$, Faez Firdaus Abdullah Jesse ${ }^{1,3}$, Mokrish Ajat ${ }^{4}$, \\ Mark Hiew Wen Han ${ }^{1}$, Wan Nor Fitri ${ }^{1}$, Muhammad Sanusi Yahaya ${ }^{1}$ and Mohammed Saad M. Alamaary
}

\begin{abstract}
1. Department of Veterinary Clinical Studies, Faculty of Veterinary Medicine, Universiti Putra Malaysia, Serdang, Selangor Darul Ehsan, Malaysia; 2. Department of Theriogenology, Faculty of Veterinary Medicine, University of Maiduguri, Maiduguri, Nigeria; 3.Institute of Tropical Agriculture and Food Security, Universiti Putra Malaysia, Serdang, Selangor Darul Ehsan, Malaysia; 4. Department of Veterinary Pre Clinical Science, Faculty of Veterinary Medicine, Universiti Putra Malaysia, Serdang, Selangor Darul Ehsan, Malaysia.

Corresponding author: Abd Wahid Haron, e-mail: wahidh@upm.edu.my

Co-authors: IDP: innocentd.peter@unimaid.edu.ng, FFAJ: jesse@upm.edu.my, MA: mokrish@upm.edu.my, MHWH: markhiew5@gmail.com, WNF: wannorfitri@gmail.com, MSY: amsyzur@yahoo.co.uk, MSMA: mss181@hotmail.com Received: 08-07-2018, Accepted: 12-09-2018, Published online: 20-10-2018
\end{abstract}

doi: 10.14202/vetworld.2018.1466-1472 How to cite this article: Peter ID, Haron AW, Jesse FFA, Ajat M, Han MHW, Fitri WN, Yahaya MS, Alamaary MSM (2018) Opportunities and challenges associated with fecal progesterone metabolite analysis, Veterinary World, 11(10): 1466-1472.

\begin{abstract}
Conventionally, plasma or milk progesterone evaluations are used to determine the reproductive status of female animals. Collection of such samples is often associated with difficulties of animal handling and restraint. Measurable quantities of progesterone metabolites are found in feces of animals. Their concentrations are known to be well correlated to plasma progesterone levels and are, therefore, used as non-invasive samples for assessing reproductive function in a wide range of animal species. Although the analysis of fecal progesterone metabolites has been widely accepted in many laboratories, several factors are known to affect the results from this valuable analytical technique. Some of these factors include storage/ transportation media for fecal samples, type of solvent that is used for extraction of progesterone metabolites from feces, and the type and sensitivity of an assaying technique employed. Although fecal progesterone metabolites analysis is associated with some difficulties, it can effectively be used to monitor reproductive function in a wide range of animal species. This review aims to highlight the usefulness of fecal progesterone metabolite analysis as a non-invasive technique in monitoring reproductive function in animals. The article mainly focuses on the many opportunities and challenges associated with this analytical technique.
\end{abstract}

Keywords: non-invasive methods, progesterone metabolite, progesterone, reproductive cycles.

\section{Introduction}

In mammals, native progesterone is mainly synthesized by the ovary, the adrenal gland, and placenta $[1,2]$. Progesterone regulates the estrous cycle and is the principal hormone responsible for the maintenance of pregnancy in female animals [1]. Native progesterone is synthesized from cholesterol after its conversion to pregnenolone by cytochrome $\mathrm{P} 450 \mathrm{scc}$, a protein located in the inner surface of the inner mitochondrial membrane. Pregnenolone is further converted into progesterone in a reaction that is catalyzed by 33-hydroxysteroid dehydrogenase (Figure-1) [3]. Progesterone is metabolized by the liver into several metabolites and are thereafter excreted in feces (Figure-1) [4-8]. There are at least 18 progesterone metabolites (2 pregnanediones, 8 mono-hydroxylated pregnanes, and 8 di-hydroxylated pregnanes), each having a unique chemical structure

Copyright: Peter, et al. Open Access. This article is distributed under the terms of the Creative Commons Attribution 4.0 International License (http://creativecommons.org/licenses/by/4.0/), which permits unrestricted use, distribution, and reproduction in any medium, provided you give appropriate credit to the original author(s) and the source, provide a link to the Creative Commons license, and indicate if changes were made. The Creative Commons Public Domain Dedication waiver (http://creativecommons.org/ publicdomain/zero/1.0/) applies to the data made available in this article, unless otherwise stated. and polarity [5,9-11]. Excretion time of progesterone metabolites has been found to take a fairly long time in non-ruminants (approximately $48 \mathrm{~h}$ ) than in ruminants (12-24 h) [12-15].

A better understanding of fundamental reproductive processes in animals is dependent on the collection of blood samples and analysis of reproductive hormones therein. However, in most animal species, the collection of blood samples is accompanied with stress and difficulties of animal handling and restraint, and in some cases, there may be a need for expertise [9,16-19]. This is even more difficult especially in aquatic and some free-living terrestrial animals $[2,20,21]$. Furthermore, the stress of blood sample collections could increase the risks of abortion and or death of the dam, especially in early pregnancies in some species of animals $[22,23]$. These issues have led to the development of non-invasive techniques to study reproductive processes using fecal samples. This methodology has gained considerable importance due to the ease of sample collection and analysis [18,20-22,24]. Although sedatives and tranquilizers are indicated for restraint in free-ranging and intractable animals, chemical restraint methods are known to pose significant health risks and could alter plasma progesterone concentrations [25-27]. Other non-invasive samples such as urine and milk samples 


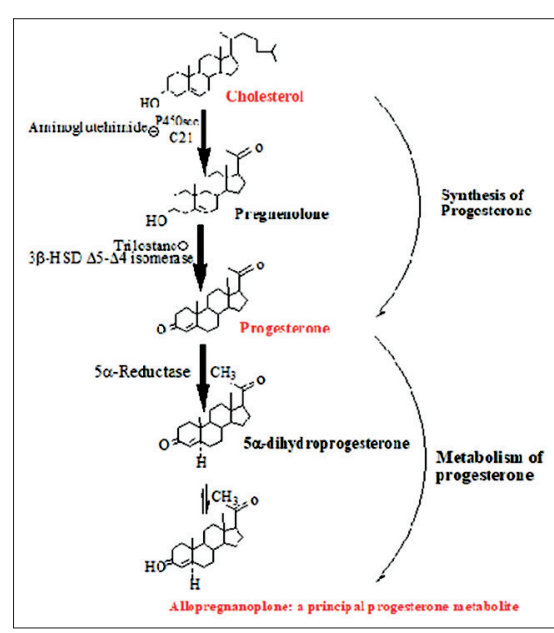

Figure-1: Conversion of cholesterol to progesterone and metablolism of progesterone into one of its principle metabolite, alporegnanolone (Illustration made using chemdraw, perkinelmwr informatics).

can be used for such purpose in animals, the simplicity of obtaining fecal samples offers a superior advantage $[28,29]$. Milk samples are usually obtained from lactating animals while urine samples will require the fixing of catheters and some animal restraint. Fecal samples, however, can be collected at any time with ease and without any stress or restraint $[23,24,30,31]$.

The development of non-invasive techniques to study reproductive and endocrinological processes in animals was primarily developed to circumvent the difficulties and stress associated with blood sample collection. Non-invasive techniques offer opportunities and can be applied in a wide range of animal species. However, there are challenges associated with such non-invasive methods. These involve problems ranging from choice of appropriate transport and storage media for fecal samples to sensitivity and specificity of a chosen assay technique employed in non-invasive technologies. This review aims to discuss the opportunities and challenges associated with the study of fecal progesterone metabolite as a non-invasive tool in the assessment of reproductive function in animals.

\section{Progesterone Metabolites Deposits in Sample Matrices}

There is quite a lot of literature on studies relating to steroid hormones and reproduction in cattle using samples such as blood, milk, fecal, or hair samples [32]. These matrices have unique characteristics and also have advantages and disadvantages. Blood samples remain the optimum sample for determination of reproductive function in animals as this sample provides the true concentration of circulating steroid hormones at any given time [12]. Collection of blood, milk, and hair samples requires animal restraint. Restraint in animals for blood sample collection is already known to be a difficult and stressful procedure. Milk sample collection is limited to lactating animals and collection will also require restraint. To determine short-term steroid levels in animals, blood, milk, and feces are preferred samples [32]. Hair samples are better suited for the determination of long term steroid hormones levels as hair is not affected by the pulsatile release of the hormone into bloodstream [33]. This allows hormones to accumulate in hair throughout its growth, making it possible to assess long-term gonadal activity without the need for serial and continuous sample analysis in animals [34]. So far, some studies have reported having used hair progesterone concentrations for determining reproductive function in animals [32,35]. However, such studies revealed weak correlations between hair progesterone concentrations and ovarian activity. This, therefore, necessitates the need for in-depth investigations to elucidate on the mechanism of steroid deposition in hair and validation of the analysis of hair steroid hormone concentrations before its reliable application in applied research in animals.

\section{Fecal Progesterone Metabolite Analysis Technologies}

Immunological techniques such as radioimmunoassay (RIA) or enzyme immunoassay designed for progesterone relies on specific or broad-spectrum antibodies and have been frequently used to measure progesterone and its immunoreactive metabolites in fecal samples $[6,7,10,17,18,27,36]$. Using either assay, it is possible to characterize ovarian cycles [16], screen open cows [10], and assess reproductive function in wildlife $[8,36-40]$. The choice of which immunological technique to employ is dependent on factors such as assay technique involved, type of information required, route of excretion of the metabolites, as well as the practicability of sample collection $[18,19]$.

Other analytical methods such as high-performance liquid chromatography (HPLC) have been developed and are frequently used in several laboratories for quantifying progesterone metabolites in biological samples $[7,19,41,42]$. HPLC separates progesterone metabolites according to their respective properties $[9,10,36,43]$. Separation is easily carried out on a reverse phase HPLC stationary phase and an isocratic solvent system using acetonitrile and distilled water at different proportions [25]. Gas chromatography-mass spectrometry (MS), a variant of HPLC, has equally been employed in the analysis of progesterone metabolites. This technique has been shown to provide very accurate results in terms of concentrations of progesterone metabolite in different sample matrices [36].

\section{Application of fecal steroid analysis}

Several studies have demonstrated that plasma progesterone concentrations and fecal progesterone metabolites are correlated $[9,13,30,44]$. Based on this similarity, progesterone metabolite evaluations have been used to study the reproductive physiology of many animals [21]. Some indicators of reproductive function in animals have been successfully determined using fecal progesterone evaluations $[5,8,16,40]$. Non-invasive 
methodologies allow for long-term monitoring of endocrine parameters without necessarily causing undue disturbance to the animal under investigation $[27,45]$. Results of progesterone metabolite evaluations that are used in assessment in fecal samples from several animals species are presented in Table-1 $[2,7,8,14-$ $17,20,21,25,39,40,42,44,46-70]$. Fecal progesterone metabolite analysis has so far been applied in several species of animals, namely whales [8], deer $[16,45]$, cattle [25], goats [30], sheep [46], felids [71], rhinoceros [72], hamsters [47], elephant [48], gazelle [49] and baboons [73], and hippopotamus [50].

\section{Challenges in the Analysis of Fecal Progesterone Metabolite Analysis}

Although the use of fecal samples offers ease of sampling as compared to blood collection, there are a number of challenges that are associated with using this sample matrix for analysis.

\section{Transport and storage of fecal samples}

Most times, it takes a fairly long time for samples to arrive at the laboratory for analysis. Failure to properly preserve fecal samples allows gut bacteria and their enzymes to further metabolize progesterone metabolites therein [19,74-76]. At present, there is no consensus on the best method of preserving fecal samples. Fecal samples from cows have been reported to have a significant decrease in total progesterone metabolite levels over short- and medium-term storage without preservatives [42,72].

To obtain accurate results from the analysis of fecal progesterone metabolite analysis, samples ought to be analyzed soon after excretion [77,78]. The concentration of progesterone metabolites in feces decreases significantly when left at ambient environmental conditions without preservation [42]. Transport and preservation of fecal samples are best

Table-1: Application of fecal progesterone metabolite analysis in assessing reproductive function in animals.

\begin{tabular}{|c|c|c|c|c|}
\hline $\begin{array}{l}\text { Reproductive } \\
\text { parameter }\end{array}$ & Species & Major metabolite & Type of assay & Reference \\
\hline $\begin{array}{l}\text { Ovarian function } \\
\text { estrus cycle }\end{array}$ & $\begin{array}{l}\text { Cows } \\
\text { Deer } \\
\text { Anteater } \\
\text { Elephant } \\
\text { Sheep } \\
\text { Gazelle } \\
\text { Hamsters } \\
\text { Rhinoceros } \\
\text { Rhinoceros Whale } \\
\text { Jaguars } \\
\text { Panda } \\
\text { Monkeys } \\
\text { Sea otters } \\
\text { Warthogs } \\
\text { Dholes } \\
\text { Sloth } \\
\text { Mink } \\
\text { Numbat } \\
\text { Armadillos } \\
\text { Hippopotamus } \\
\text { Aoudad } \\
\text { Takin } \\
\text { Python } \\
\text { Pronghorn }\end{array}$ & $\begin{array}{l}\text { 5a-pregnan-3a-ol-20-one } \\
- \\
- \\
5 a-P-3 O H \\
\text { Pregnanediol-3-glucuronide } \\
- \\
- \\
- \\
\text { Pregnanediol-3-glucuronide } \\
- \\
- \\
- \\
- \\
- \\
- \\
\text { pregnanediol-glucuronide } \\
- \\
- \\
- \\
\text { pregnanediol-3-glucuronide } \\
- \\
- \\
- \\
-\end{array}$ & $\begin{array}{l}\text { RIA/HPLC } \\
\text { EIA } \\
\text { EIA } \\
\text { EIA } \\
\text { EIA } \\
\text { EIA } \\
\text { RIA } \\
\text { EIA } \\
\text { RIA } \\
\text { HPLC } \\
\text { EIA } \\
\text { EIA } \\
\text { RIA } \\
\text { EIA } \\
\text { EIA } \\
\text { RIA/EIA } \\
\text { EIA/HPLC } \\
\text { EIA } \\
\text { EIA } \\
\text { EIA } \\
\text { EIA } \\
\text { EIA } \\
\text { EIA } \\
\text { HPLC }\end{array}$ & $\begin{array}{l}\text { Rabiee et al. [7], Yimer et al. [25], } \\
\text { Masunda et al. [42], } \\
\text { Desaulniers et al.[44] } \\
\text { Pereira et al. [16], Polegato et al.[52] } \\
\text { Knott et al.[53] } \\
\text { Ghosal et al. [20], Illera et al. [21], } \\
\text { Ghosal et al. [48], } \\
\text { Thitaram et al.,[54] } \\
\text { Čebulj-Kadunc et al.[46] } \\
\text { Mohammed et al. [49], } \\
\text { Wojtusik et al.[55] } \\
\text { Chelini et al.[47] } \\
\text { Schwarzenberger et al. [39], } \\
\text { Van der Goot et al..[56] } \\
\text { Rolland et al.[8] } \\
\text { Conforti et al.[57] } \\
\text { Budithi et al.[58] } \\
\text { Silvestre et al.[59] } \\
\text { Larson et al..40] } \\
\text { Berger et al.[60] } \\
\text { Khonmee et al.[61] } \\
\text { Troll et al.[17] } \\
\text { Nagl et al.[47] } \\
\text { Hogan et al.[62] } \\
\text { Howell-Stephens et al..[63] } \\
\text { Flacke et al.[50] } \\
\text { Abáigar et al.[14] } \\
\text { Adkin et al.[15] } \\
\text { Bertocchi et al..[64], Curry et al.[69] } \\
\text { Kersey et al. [65] }\end{array}$ \\
\hline Pregnancy & $\begin{array}{l}\text { Leopard cat } \\
\text { Cows } \\
\text { Deer } \\
\text { Gazelle } \\
\text { Panda } \\
\text { Zebra } \\
\text { Dugongs } \\
\text { Deer }\end{array}$ & 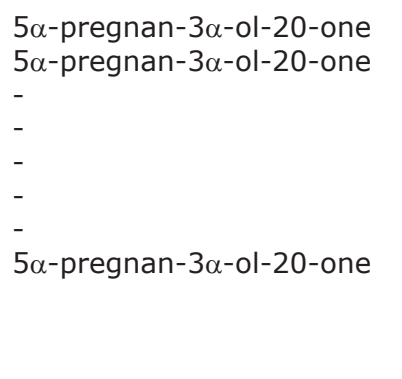 & $\begin{array}{l}\text { HPLC } \\
\text { EIA } \\
\text { EIA } \\
\text { EIA } \\
\text { EIA } \\
\text { EIA } \\
\text { EIA } \\
\text { EIA/HPLC }\end{array}$ & $\begin{array}{l}\text { Hogan et al. [62], Adachi et al.[66] } \\
\text { Howell-Stephens et al. [63], } \\
\text { Isobe et al.[67] } \\
\text { Pereira et al. [16], Knott et al. [53], } \\
\text { Krepschi et al.[68] } \\
\text { Mohammed et al. [49], } \\
\text { Wojtusik et al.[55] } \\
\text { Bertocchi et al. [64], Curry et al.[69] } \\
\text { Kersey et al.[65], Ncube et al. [65,70] } \\
\text { Burgess et al..[2] } \\
\text { Mithileshwari et al. [51] }\end{array}$ \\
\hline Anestrus & $\begin{array}{l}\text { Gazelle } \\
\text { Aoudad }\end{array}$ & & $\begin{array}{l}\text { EIA } \\
\text { EIA }\end{array}$ & $\begin{array}{l}\text { Van der Goot et al.[56] } \\
\text { Abáigar et al. [14] }\end{array}$ \\
\hline
\end{tabular}

EIA=Enzyme immunoassasy, RIA=Radioimmunoassasy, HPLC=High-performance liquid chromatography 
achieved by storage in methanol or ethanol before analysis. Such medium ensures stabilization of progesterone metabolites for several weeks $[72,79,80]$. Both chemicals have bacteriostatic properties and can also inactivate several bacterial enzymes [78,81]. Ethanol is a good preservative for samples relating to such studies [75], but the practicability of using this preservative under field conditions is quite challenging. Most often, sampling is done at remote locations and transportation from sampling site to the laboratory with such hazardous compounds poses some health hazard. Furthermore, samples that contain more than $24 \%$ alcohol are considered explosive and also classified as flammable which will require more care while handling [75].

Alternatively, fecal samples can be dried, or an on-field extraction can be performed or even carry out a solid phase extraction. These methods are considered to be alternative methods for processing fecal samples after collection for later use [72]. Drying of fecal samples is reported to be able to stabilize progesterone metabolites for up to 180 days [72].

Freezing fecal samples soon after collection is another valuable method of preserving progesterone metabolites in fecal sample $[72,82]$. Unfortunately, freezing of fecal samples is not always possible as in sometimes, sampling is done in remote locations where the habitat of free-ranging animals may be far away from sources of electricity necessary for refrigeration [72,83]. Even when such facilities are available in the field, there is the tendency that freezers and refrigerators quickly fill up with bulky fecal materials.

\section{Extraction protocol}

The extraction of progesterone metabolites from the fecal sample for determination of reproductive function is a common procedure in several laboratories. Despite the widespread use of such a technique, the comparison of results between laboratories is difficult due to the variation in extraction methods and choice of analytical technique adopted by different laboratories $[11,25,43,84,85]$. Furthermore, the differences observed in metabolism and excretory pattern of steroid hormones in different species and breeds of animals makes extrapolation of results much more difficult and sometimes misleading [18]. Commonly employed extraction procedure for progesterone metabolites includes vortexing a known weight of dried or wet fecal sample suspended in an extraction solvent usually ethanol or methanol $[5,7,10]$. To get maximum recovery of progesterone metabolites from fecal samples, certain laboratories increase the number of extraction steps. This procedure is also believed to eliminate the effects of disturbing elements from the fecal matrix. Most often, two or more solvents are used in the extraction of progesterone metabolites of known polarities from feces. Polar metabolites are preferably extracted in distilled water while non-polar metabolites are extracted in hexane and ether [86].
Specificity of assay systems used in the analysis of fecal progesterone metabolites

Due to their widespread availability and their all-encompassing nature, progesterone and immunoassays are continuously used to quantify progesterone metabolites in feces [5]. Native progesterone, however, is not found in feces or only present in minute amounts [51]. Antibodies used in the development of such kits are very specific for progesterone, and they also cross-react with progesterone metabolites in feces. Such cross-reactivity is mainly due to structural similarities between progesterone and its several metabolites. The use of such kits for progesterone metabolite evaluation in feces is, therefore, less suitable. Results obtained from diagnostic kits manufactured with antibodies to progesterone only give concentrations of total immunoreactive metabolites in the sample matrix [5]. Progesterone metabolites are generally categorized as $5 \alpha$ or $5 \beta$ pregnanes based on the presence of either a 20 -oxo, or a $20 \alpha$, or rather a $20 \beta-\mathrm{OH}$ group [5]. Enzyme immunoassays that are developed with group-specific antibodies would, therefore, provide more accurate and reliable results [51].

Results obtained from LC-MS and HPLC are more accurate and serve as valid alternatives to the ambiguous nature of results provided by immunoassay systems. LC techniques offer higher specificity over immunoassay systems and can be used in quantifying individual metabolite. However, limitations do exist in terms of cost and availability. In addition, requisite expertise is often required for LC techniques [85].

\section{Other factors}

Other lesser factors affecting the analysis of progesterone metabolites in feces are feeding and feed intake, as well as factors affecting the metabolism of progesterone. Rabiee [7] and Hutchinson et al. [87] both opined that feed and dry matter intake affect the total concentration of progesterone metabolites in feces of cows. Furthermore, feed restricted cows have been shown to have a higher concentration of progesterone metabolites in feces [7]. In other studies, it was shown that excretion rates of progesterone metabolites were found to be affected by the total weight of excreted feces [6]. Metabolism of progesterone has also been shown to be affected by the percentage of dry matter intake as well as other diet composition.

\section{Conclusion}

Although measurements of plasma progesterone remain the ideal choice for deterring reproductive function in animals, fecal progesterone metabolite evaluations can be conveniently used as an alternative method for the same purpose. Collection of fecal samples is quite easy, and multiple samples can be collected over time. However, factors such as the degradative activity of fecal bacteria on progesterone metabolites, transportation conditions, storage, and extraction method, as well as sensitivity and specificity of assays affect results. This challenge can be 
addressed with the use of appropriate preservation and extraction methods as well as utilizing sensitive and specific assay systems for analyzing progesterone metabolite concentration in feces.

\section{Author's Contributions}

AWH, IDP, and FFAJ conceived the idea and designed the main frame of this manuscript as part of IDP's research work under the supervision of AWH. IDP made the first draft and was read and corrected by AWH, FFJA, MA, and MHWH. IDP wrote the second draft, which WNF, MSY, and MSMA critically read and revised the manuscript for intellectual content All authors read and approved the final manuscript.

\section{Acknowledgments}

The authors wish to acknowledge the valuable contributions they have received from the Dean and members of other research groups from the Faculty of Veterinary Medicine, Universiti Putra Malaysia while preparing this manuscript.

\section{Competing Interests} interests.

The authors declare that they have no competing

\section{References}

1. Asher, G., Peterson, A. and Duganzich, D. (1989) Adrenal and ovarian sources of progesterone secretion in young female fallow deer, Dama dama. J. Reprod. Fertil., 85(2): 667-675.

2. Burgess, E.A., Lanyon, J.M., Brown, J.L., Blyde, D. and Keeley, T. (2012) Diagnosing pregnancy in free-ranging dugongs using fecal progesterone metabolite concentrations and body morphometrics: A population application. Gen. Com. Endocrinol., 177(1): 82-92.

3. Al-Asmakh, M. (2007) Reproductive functions of progesterone. Middle East Fertil. Soc. J., 12(3): 147-152.

4. Schwarzenberger, F., Toma, S.K., Hole, C.D., Matern, B. and Mi, S.E. (1996c) Measurement of fecal steroids in the black rhinoceros (Diceros bicornis) using group-specific enzyme immunoassays for 20-oxo-pregnanes. Zoo Biol., 15(2): 159-171.

5. Schwarzenberger, F., Palme, R. Bamberg, E. and Möstl, E. (1997) A Review of Faecal Progesterone Metabolite Analysis for Non-Invasive Monitoring of Reproductive Function in Mammals. Zeitschrift Fuer Saeugetierkunde, Germany.

6. Rabiee, A., Macmillan, K. and Schwarzenberger, F. (2001) The effect of level of feed intake on progesterone clearance rate by measuring faecal progesterone metabolites in grazing dairy cows. Anim. Reprod. Sci., 67(3-4): 205-214.

7. Rabiee, A.R., Macmillan, K.L. and Schwarzenberger, F. (2002) Plasma, milk and faecal progesterone concentrations during the oestrous cycle of lactating dairy cows with different milk yields. Anim. Reprod. Sci., 74(3-4): 121-131.

8. Rolland, R.M., Hunt, K.E., Kraus, S.D. and Wasser, S.K. (2005) Assessing reproductive status of right whales (Eubalaena glacialis) using fecal hormone metabolites. Gen. Comp. Endocrinol., 142(3): 308-317.

9. Schwarzenberger, F., Möstl, E., Palme, R. and Bamberg, E. (1996a) Faecal steroid analysis for non-invasive monitoring of reproductive status in farm, wild and zoo animals. Anim. Reprod. Sci., 42(1-4): 515-526.

10. Kornmatitsuk, B., Thitaram, C. and Kornmatitsuk, S. (2007) Measurement of faecal progesterone metabolites and its application for early screening of open cows post-insemination. Reprod. Domest. Anim., 42(3): 238-242.

11. Palme, R., Touma, C., Arias, N., Dominchin, M. and Lepschy, M. (2013) Steroid extraction: Get the best out of faecal samples. Wien. Tierarztl. Monatsschr., 100(9-10): 238-246.

12. Kumar, A., Mehrotra, S., Dangi, S.S., Singh, G., Chand, S., Singh, L., Mahla, A.S., Kumar, S. and Nehra, K. (2013) Faecal steroid metabolites assay as non-invasive monitoring of reproductive status in animals. Vet. World, 6(1): 59-63.

13. Valenzuela-Molina, M., Atkinson, S., Mashburn, K., Gendron, D. and Brownell, R.L. (2018) Fecal steroid hormones reveal reproductive state in female blue whales sampled in the Gulf of California, Mexico. Gen. Comp. Endocrinol., 261(1): 127-135.

14. Abáigar, T., Domene, M.A. and Cassinello, J. (2012) Characterization of the estrous cycle and reproductive traits of the aoudad (Ammotragus lervia) in captivity. Theriogenology, 77(9): 1759-1766.

15. Adkin, A., Bernier, D. and Santymire, R.M. (2012) Characterizing the behavior and reproductive biology of zoo-housed Sichuan takin (Budorcas taxicolor Tibetan) using non-invasive techniques. Theriogenology, 78(3): 483-494.

16. Pereira, R.J.G., Polegato, B.F., de Souza, S., Negrão, J.A. and Duarte, J.M.B. (2006) Monitoring ovarian cycles and pregnancy in brown brocket deer (Mazama gouazoubira) by measurement of fecal progesterone metabolites. Theriogenology, 65(2): 387-399.

17. Troll, S., Gottschalk, J., Seeburger, J., Ziemssen, E., Häfner, M., Thielebein, J. and Einspanier, A. (2013) Characterization of the ovarian cycle in the two-toed sloths (Choloepus didactylus): An innovative, reliable, and noninvasive method using fecal hormone analyses. Theriogenology, 80(3): 275-283.

18. Brown, J.L. (2018) Comparative ovarian function and reproductive monitoring of endangered mammals. Theriogenology, 109(1): 2-13.

19. Silva, A.R., Moreira, N., Pereira, A.F., Peixoto, G.C., Maia, K.M., Campos, L.B. and Borges, A.A. (2017) Estrus Cycle Monitoring in Wild Mammals: Challenges and Perspectives. Theriogenology Rita Payan Carreira, IntechOpen, London, UK.

20. Ghosal, R., Kalaivanan, N., Sukumar, R. and Seshagiri, P.B. (2012) Assessment of estrus cyclicity in the Asian elephant (Elephas maximus) by measurement of fecal progesterone metabolite $5 \alpha-\mathrm{P}-3 \mathrm{OH}$, using a non-invasive assay. Gen. Comp. Endocrinol., 175(1): 100-108.

21. Illera, J.C., Silván, G., Cáceres, S., Carbonell, M.D., Gerique, C., Martínez-Fernández, L., Munro, C. and Casares, M. (2014) Assessment of ovarian cycles in the African elephant (Loxodonta africana) by measurement of salivary progesterone metabolites. Zoo Biol., 33(3): 245-249.

22. Cao, X., Wei, H., Xue, H., Li, X., Zhao, W., Xu, C. and $\mathrm{Xu}, \mathrm{B}$. (2016) Fecal progestin concentrations as an indicator of reproductive success in American mink. Anim. Reprod. Sci., 165(1): 11-16.

23. Souza, N.P., Furtado, P.V. and da Paz, R.R. (2012) Noninvasive monitoring of the estrous cycle in captive crab-eating foxes (Cerdocyon thous). Theriogenology, 77(2): 233-239.

24. Sontakke, S.D. (2018) Monitoring and controlling ovarian activities in wild ungulates. Theriogenology, 109(2): 31-41.

25. Yimer, N., Rosnina, Y., Wahid, H., Bukar, M.M., Malik, A., Yap, K.C., Fahmi, M., Ganesamurthi, P. and Saharee, A. (2012) Fecal progestin extraction and analysis for non-invasive monitoring of ovarian cycle in beef cows. Pak. Vet. J., 32(4): 584-588.

26. Kusuda, S., Doi, O., Naito, H. and Hashikawa, H. (2017) Puberty, ovarian cycle, pregnancy, and postpartum ovulation in captive Sichuan golden monkeys (Rhinopithecus 
roxellana) based on changes in urinary and fecal gonadal steroid metabolites. Theriogenology, 87(1): 179-186.

27. Umapathy, G., Kumar, V., Kabra, M. and Shivaji, S. (2013) Detection of pregnancy and fertility status in big cats using an enzyme immunoassay based on $5 \alpha$-pregnan-3 $\alpha$-ol-20one. Gen. Comp. Endocrinol., 180(1): 33-38.

28. Lopez, H., Bunch, T. and Shipka, M. (2002) Estrogen concentrations in milk at estrus and ovulation in dairy cows. Anim. Reprod. Sci., 72(1-2): 37-46.

29. Stronge, A., Sreenan, J., Diskin, M., Mee, J., Kenny, D. and Morris, D. (2005) Post-insemination milk progesterone concentration and embryo survival in dairy cows. Theriogenology, 64(5): 1212-1224.

30. Capezzuto, A., Chelini, M., Felippe, E. and Oliveira, C. (2008) Correlation between serum and fecal concentrations of reproductive steroids throughout gestation in goats. Anim. Reprod. Sci., 103(1-2): 78-86.

31. Ahuja-Aguirre, C., López-deBuen, L., Rojas-Maya, S. and Hernández-Cruz, B.C. (2017) Progesterone and estradiol profiles in different reproductive stages of captive collared peccary (Pecari tajacu) females assessed by fecal metabolites. Anim. Reprod. Sci., 180(1): 121-126.

32. Tallo-Parra, O., Carbajal, A., Monclús, L., Manteca, X. and Lopez-Bejar, M. (2018) Hair cortisol and progesterone detection in dairy cattle: Interrelation with physiological status and milk production. Dom. Anim. Endocrinol., 64(1): 1-8.

33. Ventrella, D., Elmi, A., Barone, F., Carnevali, G., Govoni, N. and Bacci, M. (2018) Hair testosterone and cortisol concentrations in pre-and post-rut roe deer bucks: Correlations with blood levels and testicular morphometric parameters. Animals, 8(7): 113.

34. Stalder, T. and Kirschbaum, C. (2012) Analysis of cortisol in hair-state of the art and future directions. Brain Behav. Immun., 26(7): 1019-1029.

35. Liu, X., Chen, F., Guo, D., Song, X. and Zhong, Y. (1988) Early pregnancy diagnosis in dairy cows based on hair progesterone analysis. Int. J. Anim. Sci., 3(2): 123-127.

36. Wasser, S., Monfort, S., Southers, J. and Wildt, D. (1994) Excretion rates and metabolites of oestradiol and progesterone in baboon (Papio cynocephalus cynocephalus) faeces. J. Reprod. Fertil., 101(1): 213-220.

37. Pereira, R.J., Polegato, B.F., de Souza, S., Negr ao, J.A. and Duarte J.M. (2006) Monitoring ovarian cycles and pregnancy in brown brocket deer (Mazama gouazoubira) by measurement of fecal progesterone metabolites. Theriogenology, 65(2): 387e99.

38. Wasser, S.K., Velloso, A.D.L. and Rodden, M.D. (1995) Using fecal steroids to evaluate reproductive function in female maned wolves. J. Wildl. Manage., 59(4): 889-894.

39. Schwarzenberger, F., Walzer, C., Tomasova, K., Vahala, J., Meister, J., Goodrowe, K.L., Zima, J., Strauss, G. and Lynch, M. (1998) Faecal progesterone metabolite analysis for non-invasive monitoring of reproductive function in the white rhinoceros (Ceratotherium simum). Anim. Reprod. Sci., 53(1-4): 173-190.

40. Larson, S., Casson, C.J. and Wasser, S. (2003) Noninvasive reproductive steroid hormone estimates from fecal samples of captive female sea otters (Enhydra lutris). Gen. Comp. Endocrinol., 134(1): 18-25.

41. Schwarzenberger, F., Son, C., Pretting, R. and Arbeiter, K. (1996b) Use of group-specific antibodies to detect fecal progesterone metabolites during the estrous cycle of cows. Theriogenology, 46(1): 23-32.

42. Masunda, B., Mutisi, C., Hamudikuwanda, H. and Agumbah, J. (1999) The concentration of faecal progestins during the oestrous cycle in nkone cows and the effect of duration of storage of faecal samples at room temperature on faecal progestin levels. Trop. Anim. Health Prod., 31(6): 373-381.

43. Shideler, S., Ortuno, A., Moran, F., Moorman, E. and Lasley, B. (1993) Simple extraction and enzyme immunoassays for estrogen and progesterone metabolites in the feces of Macaca fascicularis during non-conceptive and conceptive ovarian cycles. Biol. Reprod., 48(6): 1290-1298.

44. Desaulniers, D.M., Goff, A.K., Betteridge, K.J., Rowell, J.E. and Flood, P.F. (1989) Reproductive hormone concentrations in faeces during the oestrous cycle and pregnancy in cattle (Bos taurus) and muskoxen (Ovibos moschatus). Can. J. Zool., 67(5): 1148-1154.

45. Nagl, A., Kneidinger, N., Kiik, K., Lindeberg, H., Maran, T. and Schwarzenberger, F. (2015) Noninvasive monitoring of female reproductive hormone metabolites in the endangered European mink (Mustela lutreola). Theriogenology, 84(9): 1472-1481.

46. Čebulj-Kadunc, N., Snoj, T. and Cestnik, V. (2000) Faecal gestagen, serum and milk progesterone concentrations in ewes of the Jezersko-Solchava breed. Acta. Vet. Brno., 69(1): 33-37.

47. Chelini, M.O.M., Souza, N.L., Rocha, A.M., Felippe, E.C.G. and Oliveira, C.A. (2005) Quantification of fecal estradiol and progesterone metabolites in Syrian hamsters (Mesocricetus auratus). Braz. J. Med. Biol. Res., 38(11): 1711-1717.

48. Ghosal, R., Sukumar, R. and Seshagiri, P.B. (2010) Prediction of estrus cyclicity in Asian elephants (Elephas maximus) through estimation of fecal progesterone metabolite: Development of an enzyme-linked immunosorbent assay. Theriogenology, 73(8): 1051-1060.

49. Mohammed, O.B., Green, D.I. and Holt, W.V. (2011) Fecal progesterone metabolites and ovarian activity in cycling and pregnant mountain gazelles (Gazella gazella). Theriogenology, 75(3): 542-548.

50. Flacke, G.L., Schwarzenberger, F., Penfold, L.M., Walker, S.L., Martin, G.B., Millar, R.P. and Paris, M.C. (2017) Characterizing the reproductive biology of the female pygmy hippopotamus (Choeropsis liberiensis) through non-invasive endocrine monitoring. Theriogenology, 102(2): 126-138.

51. Mithileshwari, C., Srivastava, T., Kumar, V., Kumar, A. and Umapathy, G. (2016) Non-invasive assessment of fecal progestagens and pregnancy detection in Himalayan musk deer (Moschus chrysogaster). Theriogenology, 85(2): 216-223.

52. Polegato, B.F., Zanetti, E.D.S. and Duarte, J.M.B. (2018) Monitoring ovarian cycles, pregnancy and post-partum in captive marsh deer (Blastocerus dichotomus) by measuring fecal steroids. Conserv. Physiol., 6(1): cox073.

53. Knott, K.K., Roberts, B.M., Maly, M.A., Vance, C.K., DeBeachaump, J., Majors, J. and Kouba, A.J. (2013) Fecal estrogen, progestagen and glucocorticoid metabolites during the estrous cycle and pregnancy in the giant anteater (Myrmecophaga tridactyla): Evidence for delayed implantation. Reprod. Biol. Endocrinol., 11(1): 83.

54. Thitaram, C. and Brown, J.L. (2017) Monitoring and controlling ovarian activity in elephants. Theriogenology, 109(2): 42-47.

55. Wojtusik, J., Brown, J.L. and Pukazhenthi, B.S. (2017) Non-invasive hormonal characterization of the ovarian cycle, pregnancy, and seasonal anestrus of the female addra gazelle (Nanger dama ruficollis). Theriogenology, 95(1): 96-104.

56. Van der Goot, A.C., Martin, G.B., Millar, R.P., Paris, M.C.J. and Ganswindt, A. (2015) Profiling patterns of fecal 20-oxopregnane concentrations during ovarian cycles in free-ranging southern white rhinoceros (Ceratotherium simum simum). Anim. Reprod. Sci., 161(1): 89-95.

57. Conforti, V.A., Bravo, N.R.S., Moreira, M.R., Villar, E.C., Paulo, O.L.O.H., Veneziani, R.C.S. and Silva, M.A. (2017) High-performance liquid chromatography as a novel tool for assessing ovarian function in jaguars (Panthera onca): Development and validation of the method and quantification of ovarian steroids. Anim. Reprod., 14(1): 361-361.

58. Budithi, N.R.B., Kumar, V., Yalla, S.K., Rai, U. and Umapathy, G. (2016) Non-invasive monitoring of 
reproductive and stress hormones in the endangered red panda (Ailurus fulgens fulgens). Anim. Reprod. Sci., 172(1): 173-181.

59. Silvestre, T., Zanetti, E.S., Duarte, J.M., Barriento, F.G., Hirano, Z.M., Souza, J.C. and Passos, F.C. (2017) Ovarian cycle of Southern brown howler monkey (Alouatta guariba clamitans) through fecal progestin measurement. Primates, 58(1): 131-139.

60. Berger, E.M., Leus, K., Vercammen, P. and Schwarzenberger, F. (2006) Faecal steroid metabolites for non-invasive assessment of reproduction in common warthogs (Phacochoerus africanus), red river hogs (Potamochoerus porcus) and babirusa (Babyrousa babyrussa). Anim. Reprod. Sci., 91(1-2): 155-171.

61. Khonmee, J., Rojanasthien, S., Thitaram, C., Sumretprasong, J., Aunsusin, A., Chaisongkram, C. and Songsasen, N. (2017) Non-invasive endocrine monitoring indicates seasonal variations in gonadal hormone metabolites in dholes (Cuon alpinus). Conserv. Physiol., 5(1): $\operatorname{cox} 001$.

62. Hogan, L.A., Lisle, A.T., Valentine, L., Johnston, S.D. and Robertson, H. (2012) Non-invasive monitoring of male and female numbat (Myrmecobius fasciatus: Myrmecobiidae) reproductive activity. Anim. Reprod. Sci., 133(3-4): 237-245.

63. Howell-Stephens, J., Bernier, D., Brown, J.S., Mulkerin, D. and Santymire, R.M. (2013) Using non-invasive methods to characterize gonadal hormonal patterns of southern threebanded armadillos (Tolypeutes matacus) housed in North American zoos. Anim. Reprod.Sci., 138(3-4): 314-323.

64. Bertocchi, M., Pelizzone, I., Parmigiani, E., Ponzio, P., Macchi, E., Righi, F. and Di Ianni, F. (2018) Monitoring the reproductive activity in captive bred female ball pythons $(P$. regius) by ultrasound evaluation and noninvasive analysis of faecal reproductive hormone (progesterone and $17 \beta$-estradiol) metabolites trends. PLoS One, 13(6): e0199377.

65. Kersey, D.C., Holland, J. and Eng, C. (2015) Reproductive activity in the peninsular pronghorn determined from excreted gonadal steroid metabolites. Zoo Biol., 34(2): $183-188$

66. Adachi, I., Kusuda, S., Nagao, E., Taira, Y., Asano, M., Tsubota, T. and Doi, O. (2010) Fecal steroid metabolites and reproductive monitoring in a female Tsushima leopard cat (Prionailurus bengalensis euptilurus). Theriogenology, 74(8): 1499-1503.

67. Isobe, N., Akita, M., Nakao, T., Yamashiro, H. and Kubota, H. (2005) Pregnancy diagnosis based on the fecal progesterone concentration in beef and dairy heifers and beef cows. Anim. Reprod. Sci., 90(3-4): 211-218.

68. Krepschi, V.G., Polegato, B.F., Zanetti, E.S. and Duarte, J.M. (2013) Fecal progestins during pregnancy and postpartum periods of captive red brocket deer (Mazama americana). Anim. Reprod. Sci., 137(1-2): 62-68.

69. Curry, E., Browning, L.J., Reinhart, P. and Roth, T.L. (2017) Integrating trans-abdominal ultrasonography with fecal steroid metabolite monitoring to accurately diagnose pregnancy and predict the timing of parturition in the red panda (Ailurus fulgens styani). Zoo Biol., 36(3): 193-200.

70. Ncube, H., Duncan, P., Grange, S., Cameron, E.Z., Barnier, F. and Ganswindt, A. (2011) Pattern of faecal 20-oxopregnane and oestrogen concentrations during pregnancy in wild plains zebra mares. Gen.Comp. Endocrinol., 172(3): 358-362.

71. Wasser, S.K., Davenport, B., Ramage, E.R., Hunt, K.E., Parker, M., Clarke, C. and Stenhouse, G. (2004) Scat detection dogs in wildlife research and management: Application to grizzly and black bears in the Yellowhead ecosystem,
Alberta, Canada. Can. J. Zool., 82(3): 475-492.

72. Galama, W.T., Graham, L.H. and Savage A. (2004) Comparison of fecal storage methods for steroid analysis in black rhinoceroses (Diceros bicornis). Zoo Biol., 23(4): 291-300.

73. Kalbitzer, U. and Heistermann, M. (2013) Long-term storage effects in steroid metabolite extracts from baboon (Papio sp.) faeces-a comparison of three commonly applied storage methods. Methods Ecol. Evol., 4(5): 493-500.

74. Möstl, E. and Palme, R., (2002) Hormones as indicators of stress. Domest. Anim. Endocrinol., 23(1-2): 67-74.

75. Terio, K.A., Brown, J.L., Moreland, R. and Munson, L. (2002) Comparison of different drying and storage methods on quantifiable concentrations of fecal steroids in the cheetah. Zoo Biol., 21(3): 215-222.

76. MÖstl, E., Rettenbacher, S. and Palme, R. (2005) Measurement of corticosterone metabolites in birds' droppings: An analytical approach. Ann. N. Y. Acad. Sci., 1046(1): 17-34.

77. Messmann, S., Bagu, E., Robia, C. and Palme, R. (1999) Measurement of glucocorticoid metabolite concentrations in faeces of domestic livestock. J. Vet. Med., 46(10): 621-631.

78. Khan, M., Altmann, J., Isani, S. and Yu, J. (2002) A matter of time: Evaluating the storage of fecal samples for steroid analysis. Gen. Comp. Endocrinol., 128(1): 57-64.

79. Wasser, S.K. and Starling, A.K. (1988) Proximate and ultimate causes of reproductive suppression among female yellow baboons at Mikumi National Park, Tanzania. A. J. Primatol., 16(2): 97-121.

80. Lynch, J., Khan, M., Altmann, J., Njahira, M. and Rubenstein, N. (2003) Concentrations of four fecal steroids in wild baboons: Short-term storage conditions and consequences for data interpretation. Gen. Comp. Endocrinol., 132(2): 264-271

81. Deng, H., Liu, S., Jin, X., Ge, X., He, L., Liu, G. and Hu, D. (2014) Research on methods of preserving fecal steroid hormones in giant panda (Ailuropoda melanoleuca). NorthWest. J. Zool., 10(1): 210-216.

82. Hunt, K.E. and Wasser, S.K. (2003) Effect of long-term preservation methods on fecal glucocorticoid concentrations of grizzly bear and African elephant. Physiol. Biochem. Zool., 76(6): 918-928.

83. Nugraha, T.P., Heistermann, M., Agil, M., Purwantara, B., Supriatna, I., Gholib, G., van Schaik, C.P. and Weingrill, T. (2017) Validation of a field-friendly extraction and storage method to monitor fecal steroid metabolites in wild orangutans. Primates, 58(2): 285-294.

84. Wasser, S.K., Monfort, S.L. and Wildt, D.E. (1991) Rapid extraction of faecal steroids for measuring reproductive cyclicity and early pregnancy in free-ranging yellow baboons (Papio cynocephalus cynocephalus). J. Reprod. Fertil., 92(2): 415-423.

85. Wynn, M.A., Esteller-Vico, A., Legacki, E.L., Conley, A.J., Loux, S.C., Stanley, S.D., Curry, T.E., Squires, E.L., Troedsson, M.H. and Ball, B.A. (2018) A comparison of progesterone assays for determination of peripheral pregnane concentrations in the late pregnant mare. Theriogenology, 106(2): 127-133.

86. Matsumuro, M., Sankai, T., Cho, F., Yoshikawa, Y. and Yoshida, T. (1999) A two-step extraction method to measure fecal steroid hormones in female cynomolgus monkeys (Macaca fascicularis). Am. J. Primatol., 48(4): 291-298.

87. Hutchinson, I.A., Dewhurst, R.J., Evans, A., Lonergan, P. and Butler, S.T. (2012) Effect of grass dry matter intake and fat supplementation on progesterone metabolism in lactating dairy cows. Theriogenology, 78(4): 878-886. 